\title{
STUDIES ON COMBINING ABILITY FOR GRAIN YIELD AND ITS COMPONENTS TRAITS IN RICE UNDER NORMAL AND WATER STRESS CONDITIONS.
}

\author{
R. A. El-Refaey ${ }^{(1)}$, A. B. El-Abd ${ }^{(2)}$ and M. A. Fetyani ${ }^{(2)}$ \\ (1) Agronomy Department, Fac. of Agric. Tanta University, Egypt. \\ (2) Rice Research Section, Field Crops Research Institute, ARC, Giza, Egypt.
}

Received: Dec. 2, 2020

Accepted: Dec. 30,2020

\begin{abstract}
Combining ability analysis was calculated for grain yield and some yield related traits in rice through $8 \times 8$ diallal set analysis excluding reciprocals at the Experimental Farm of Sakha Agricultural Research station Kafr El-Sheikh, Egypt during 2016 and 2017 summer seasons under normal and water stress conditions. Mean squares of Parents and their crosses were highly significant for all traits studied under both environments and their combined analysis, indicating that overall wide differences among these populations and reflecting the diversity at the parent and their crosses for the studied traits.
\end{abstract}

GCA and SCA mean squares were found to be highly significant for all traits studied under both environments indicating that the role of additive and non - additive gene action in the expressions of these traits. The ratio of GCA/SCA was less than unity for all traits under both environments, except for grain yield /plant under stress condition, indicating that non - additive gene action was more responsible for the inheritance of these traits. The variety IRAT 170 and Morobroken could be used as a good combiner parents for grain yield /plant and some of its components under normal as well as stress conditions due to its significant and/or highly significant $\left(\mathrm{gi}^{\wedge}\right)$ in positive direction while the parental varieties; Giza 177, Giza 178 and Giza 179 behaved as good combiner for No. of days to $50 \%$ heading under both environmental conditions. The crosses; Sakha $106 \mathrm{x}$ Giza 179, Giza177 x IET1444, Giza 177 x Morobroken, Giza178 x Giza 179, Giza 178 x Morobroken and IET $1444 \times$ Morobroken had significant $\left(S_{\text {iij }}\right)$ in positive direction under normal condition for grain yield and some of its components. While the crosses; Sakha 106 x Giza 177, Sakha 106 x Giza 179 and Giza 178 x Giza 179 had significant ( $\left(_{\text {ij }}\right)$ in positive direction for grain yield and some of its components under stress condition.

Key words: GCA, SCA, additive gene, non - additive gene, environmental conditions

\section{INTRODUCTION}

Rice (Oryza sativa L.) is one of the most important cereal crops in Egypt. The cultivated rice area in Egypt has been increasing gradually since the beginning of the Egyptian Rice Program. The main target of The National Rice Program in Egypt is decreasing the total cultivated area in normal soil, conversely in water stress condition soil, with carrying out high yield potentiality from unit area. Water stress tolerance in dry land culture at the end of irrigating canals has been identified as a complex and growth stage-specific trait, largely associated with a volume and deep root system (Chang and Loresto, 1986).

Drought, like many other environmental stresses, has adverse effects on crop yield. Low water availability is one of the major causes for crop yield reduction affecting the majority of the farmed regions around the world. As water resources for agronomic uses become more limiting, the 
development of drought-tolerant lines becomes increasingly more important.

The breeding of qualitatively yield-rich rice varieties is not possible without prior knowledge of their genetic properties. The breeders - therefore - try with the help of suitable quantitative genetic methods, to combine the desired properties of different varieties. The diallel-cross method which was suggested by (Griffing (1956 a and b). is one at the most methods used to determine the type at gene actions vis general and specific combining abilities. Consequently, crossing in a diallel fashion is the only specific and effective technique for the measurement, identification and selection of superior genotypes. Estimating combining ability through diallal analysis is the first step in most plant-breeding programs aimed to improving yield and other related parameters (Pickett 1993; Griffing 1956 a).

Estimates of additive and non-additive gene action are important in early stages of breeding procedures (Dudley and Moll 1969). Selection would be successful during the early generations when additive gene action is predominant. Otherwise, the selection would be at later generations when these effects are fixed in homozygous lines. The present investigation aimed to estimate the general and specific combining ability, nature of gene action and their interactions with normal and water stresses conditions for grain yield and its related traits in rice.

\section{MATERIALS AND METHODS}

The present investigation was carried out at the Experimental Farm of Sakha Agricultural Research station, Kafr ElSheikh, Egypt during 2016 and 2017 rice growing seasons. Eight local and exotic rice genotypes, namely, Sakha 104, Sakha 106, Giza 177, Giza 178, Giza 179, IET 1444, IRAT 170 and Morobroken provided from the pure genetic stock of the Rice Research Section, Field Crops Research Institute, Agricultural Research Center, were grown under normal and water stress conditions (Table 1).

In 2016 season, the above mentioned rice genotypes were planted in three successive dates of planting with ten days intervals. At flowering time, crossing among all possible combinations between the 8 parental lines excluding reciprocals were carried out following the technique proposed by Jodon (1938) and modified by Butany (1961).

Table (1): Origin and main characteristics of the eight rice genotypes used as parents in a diallel cross.

\begin{tabular}{|c|c|c|c|c|c|}
\hline No & Genotypes & Pedigree & Grain shape & Variety type & Drought tolerant \\
\hline 1 & Sakha 104 & (GZ 4096-8-1/ GZ4100-9) & Short & Japonica & Sensitive \\
\hline 2 & Sakha 106 & (GiZa177/Hexi30) & Short & Japonica & Moderate \\
\hline 3 & Giza 177 & $\begin{array}{c}\text { (GiZa171/ Yu mji } \\
\text { No.1//piNo-4) }\end{array}$ & Short & Japonica & Sensitive \\
\hline 4 & Giza 178 & (Giza175/ mi lyang49) & Short & Indica/ Japonica & Moderate \\
\hline 5 & Giza 179 & $\begin{array}{c}\text { (GZ 1368-5-5-4/GZ6296- } \\
\text { 12-1-2) }\end{array}$ & Medium & Indica/ Japonica & Moderate \\
\hline 6 & IET1444 & TN1 / CO29 & Short & Indica/ Japonica & Tolerant \\
\hline 7 & IRAT170 & IRAT13/ Palawan & long & Indica & Tolerant \\
\hline 8 & Morobroken & IR8-24-6 (M307H5) & long & Indica & Tolerant \\
\hline
\end{tabular}


In 2017 season, 30 days old seedlings of 36 produced rice genotypes ( 8 parents and $\left.28 \quad F_{1} ' s\right)$ were transplanted in permanent field at the experiment using randomized complete blocks design (RCBD) with three replications according to Snedecor and Cochran (1967). The combined analysis of variance was calculated for these two environments to examine the interaction among the genetic components for the two different environmental conditions. Each replicate comprised of 5 rows of each parent and 3 rows of each $F_{1}$ hybrids. The row was $5 \mathrm{~m}$ long and $20 \times 20 \mathrm{~cm}$ apart was maintained between rows and seedlings. Flush irrigation was used every $\mathbf{1 0}$ days for the water stress conditions. Recommended cultural practices of rice in the area were followed under the two environmental conditions. Data were collected for grain yield and its components traits l.e. , number of days to $50 \%$ heading (days), plant height $(\mathrm{cm})$, number of panicles / plant, 1000-grain weight $(\mathrm{g})$, number of filled grains / panicle, sterility percentage, and grain yield/ plant (g) traits according to the standard evaluation system of IRRI (1996).

The combining ability analysis was done according to Griffing's (1956 b), method 2, model 1, where parents and one set of $F_{1}$ 's were included to estimate the effects of general (GCA) and specific (SCA) combining abilities and variances at each one. The GCA / SCA ratio was estimated to measure the relative importance of additive gene to nonadditive gene effects (Singh and Chaudhary 1979).

The statistical analysis of variance was done using method II mode I (fixed effects) of Griffing (1956) which was considered appropriate as its all requirements were met by the experiment.

In a fixed model analysis of data from single cross progeny of a diallel, the average performance of each progeny is partitioned into components relatively to general combining ability (GCA) as main effects and specific combining ability (SCA) as interactions. The SCA is used to identify the specific combinations which perform better than would be expected on the basis of the average performance of the lines involved. But, GCA variances represent fixable (additive gene action) components that include additive and additive $x$ additive variances. On the other hand, SCA variances represent dominance and or non-additive gene action and measures the deviation of crosses from the value expected on the basis of parental performance. This includes dominance, additive $x$ dominance and dominance $x$ dominance and higher order epistatic value. If GCA mean squares are significant, but the SCA is not, one would accept the hypothesis that, the performances of a single cross progeny can be adequately predicted on the basis of additive and additive $\times$ additive types of gene action. The best performing progeny, therefore, may be produced by crossing the two parents having the highest GCA effects. If, both GCA and SCA mean squares are significant, this indicates the role of both additive as well as non-additive gene actions and using the relative sizes of mean squares, the relative importance of both is decided. Hence, GCA/SCA mean square ratio was used as a measure to understand the nature of gene action involved.

\section{RESULTS AND DISCUSSION}

1- Analysis of variance for grain yield and its component characters:

Analysis of variance for the traits studied i.e., days to $\mathbf{5 0} \%$ heading, plant height, number of panicles /plant, 1000grain weight, number of filled grains /panicle, sterility percentage and grain yield /plant under two environmental conditions are presented in Table (2). 
Statistical analysis revealed highly significant mean square of environments for plant height, No. of panicles /plant, 1000 - grain weight, No. of filled grains / panicle, sterility (\%) and grain yield /plant, indicating that the two environments (non- continue flooding stress and stress conditions) behaved in different way for these traits. While, mean square for No. of days to $50 \%$ heading , low the tow environments was not significant, that, this trait is not affected by the environments changes . In addition, mean squares due to genotypes were highly significant for all traits, indicating evidence for the presence of large amounts of genetic variability, among the studied rice genotypes which considered adequate for further biometrical assessment.
Highly significant were detected for parents and their $F_{1}$ crosses mean squares under both environments and their combined analysis, indicating that overall wide differences among these populations and reflecting the diversity of the parents and their crosses for the studied traits. Parents vs crosses mean squares were highly significant for all traits studied, except for sterility \% at normal condition, grain yield / plant under stress condition, indicating that, heterotic variance could be change from environment to another for most traits, while for the excepted traits, heterotic variance may behaved in the same way. These results are in agreement with those obtained by Gaballa (2009), Hadifa (2012) and El-Hity et al. (2015).

Table (2): Mean square estimates of ordinary and combining ability analyses for yield and its related traits for parental genotypes under normal and water stress conditions.

\begin{tabular}{|c|c|c|c|c|c|c|c|c|}
\hline \multirow{2}{*}{ S.O.V } & \multicolumn{2}{|c|}{ d.f } & \multicolumn{3}{|c|}{$\begin{array}{c}\text { Number of days to } 50 \% \\
\text { heading (day) }\end{array}$} & \multicolumn{3}{|c|}{ Plant height (cm) } \\
\hline & Single & Comb. & $\mathbf{N}$ & $\mathrm{S}$ & C & $\mathbf{N}$ & S & C \\
\hline $\mathbf{E}$ & - & 1 & - & - & 0.907 & - & - & $58,905.042^{\star \star}$ \\
\hline Replications & 2 & 5 & 0.11 & 0.01 & $10.253^{\star \star}$ & 0.11 & 0.19 & $10960.596^{\star \star}$ \\
\hline Genotypes & 35 & 35 & $234.42^{\star \star}$ & $239.15^{\star \star}$ & $424.623^{\star \star}$ & $1438.46^{\star \star}$ & $768.39^{\star \star}$ & $1276.239^{\star \star}$ \\
\hline Parents & 7 & 7 & $201.88^{\star \star}$ & $113.98^{\star \star}$ & $219.23^{\star \star}$ & $764.93^{\star \star}$ & $1069.28^{\star \star}$ & $750.31^{\star \star}$ \\
\hline Crosses & 27 & 27 & $246.84^{\star \star}$ & $280.43^{\star \star}$ & $491.19^{\star \star}$ & $1247.73^{\star \star}$ & $649.95^{\star \star}$ & $1354.93^{\star \star}$ \\
\hline $\begin{array}{l}\text { Parents vs. } \\
\text { Crosses }\end{array}$ & 1 & 1 & $126.88^{* *}$ & 0.96 & $65.19^{* *}$ & $11302.88^{\star *}$ & $1860.01^{\star *}$ & $2833.11^{\star \star}$ \\
\hline GXE & - & - & - & - & $14.117^{\star \star}$ & - & - & $205.194^{\star \star}$ \\
\hline PXE & - & - & - & - & $96.63^{\star \star}$ & - & - & $1083.9^{\star \star}$ \\
\hline Cr X E & - & - & - & - & $36.08^{\star \star}$ & - & - & $542.75^{\star \star}$ \\
\hline P vs. C X E & - & - & - & - & $62.65^{\star *}$ & - & - & $10329.78^{\star \star}$ \\
\hline Error & 70 & 175 & 2.37 & 22.69 & 22.257 & 62.89 & 27.90 & 245.179 \\
\hline GCA & 7 & 7 & $283.26^{\star *}$ & $221.02^{\star \star}$ & - & $905.33^{\star *}$ & $363.98^{\star \star}$ & - \\
\hline SCA & 28 & 28 & $26.86^{\star *}$ & $44.39^{* *}$ & - & $373.02^{\star *}$ & $229.17^{\star *}$ & - \\
\hline GCA X E & - & - & - & - & $229.794^{\star *}$ & - & - & $389.817^{\star \star}$ \\
\hline SCA X E & - & - & - & - & $31.014^{\star \star}$ & - & - & $168.429^{\star \star}$ \\
\hline Error term & 70 & 175 & 0.79 & 7.56 & 7.419 & 20.96 & 9.30 & 81.726 \\
\hline GCA/SCA & - & - & 1.084 & 0.580 & - & 0.251 & 0.161 & - \\
\hline $\begin{array}{l}\text { GCA X E/ } \\
\text { SCA X E }\end{array}$ & - & - & - & - & 7.40 & - & - & 2.31 \\
\hline $\begin{array}{l}\text { GCA X N/ } \\
\text { GCA X S }\end{array}$ & - & - & - & - & 1.28 & - & - & 2.48 \\
\hline $\begin{array}{l}\text { SCA X N/ } \\
\text { SCA } \times \text { S }\end{array}$ & - & - & - & - & 0.60 & - & - & 1.62 \\
\hline
\end{tabular}

${ }^{*}$ and ${ }^{* *}$ significant at 0.05 and 0.01 probability levels, respectively. Abbreviations: $\mathbf{N}$ normal condition and $\mathrm{S}$ water stress condition 
Table (2): Cont.

\begin{tabular}{|c|c|c|c|c|c|c|c|c|}
\hline \multirow{2}{*}{ S.O.V } & \multicolumn{2}{|c|}{ d.f } & \multicolumn{3}{|c|}{ Number of panicles/plant } & \multicolumn{3}{|c|}{1000 -grain weight (g) } \\
\hline & Single & Comb. & $\mathbf{N}$ & $\mathrm{S}$ & C & $\mathbf{N}$ & $\mathrm{S}$ & C \\
\hline$E$ & - & 1 & - & - & $274.501^{\star *}$ & - & - & $75.449^{* *}$ \\
\hline Replications & 2 & 5 & 0.13 & 0.23 & $51.903^{\star \star}$ & 0.038 & 0.041 & $24.605^{\star *}$ \\
\hline Genotypes & 35 & 35 & $134.34^{\star \star}$ & $180.04^{\star \star}$ & $222.713^{\star \star}$ & $29.538^{\star \star}$ & $28.821^{\star \star}$ & $41.649^{\star \star}$ \\
\hline Parents & 7 & 7 & $142.52^{\star \star}$ & $46.76^{\star \star}$ & $116.46^{\star \star}$ & $20.280^{\star *}$ & $9.678^{\star \star}$ & $19.44^{\star \star}$ \\
\hline Crosses & 27 & 27 & $137.16^{\star \star}$ & $208.59^{\star \star}$ & $250.71^{\star \star}$ & $27.097^{\star \star}$ & $34.380^{\star \star}$ & $47.60^{\star \star}$ \\
\hline $\begin{array}{l}\text { Parents vs. } \\
\text { Crosses }\end{array}$ & 1 & 1 & 0.66 & $341.91^{* *}$ & $210.58^{\star \star}$ & $160.23^{\star \star}$ & $12.751^{\star *}$ & $36.41^{\text {** }}$ \\
\hline GX E & - & - & - & - & $76.725^{\star *}$ & - & - & $4.782^{\star \star}$ \\
\hline PXE & - & - & - & - & $72.82^{\star \star}$ & - & - & $10.518^{\star \star}$ \\
\hline CrXE & - & - & - & - & $95.04^{\star \star}$ & - & - & $13.877^{\star \star}$ \\
\hline P vs. C X E & - & - & - & - & $131.99^{\star \star}$ & - & - & $136.579^{\star \star}$ \\
\hline Error & 70 & 175 & 2.54 & 16.68 & 29.346 & 0.561 & 2.219 & 5.598 \\
\hline GCA & 7 & 7 & $75.66^{\star *}$ & $74.92^{\star *}$ & - & $16.267^{\star *}$ & $14.827^{\star *}$ & - \\
\hline SCA & 28 & 28 & $37.06^{\star \star}$ & $56.28^{\star \star}$ & - & $8.241^{\star \star}$ & $8.302^{\star \star}$ & - \\
\hline GCA X E & - & - & - & - & $66.753^{\star \star}$ & - & - & $14.167^{\star *}$ \\
\hline SCA X E & - & - & - & - & $29.710^{\star *}$ & - & - & $5.135^{\star \star}$ \\
\hline Error term & 70 & 175 & 0.85 & 5.56 & 9.782 & 0.187 & 0.740 & 1.866 \\
\hline GCA/SCA & - & - & 0.207 & 0.137 & - & 0.200 & 0.186 & - \\
\hline $\begin{array}{l}\text { GCA X E/ } \\
\text { SCA X E }\end{array}$ & - & - & - & - & 2.24 & - & - & 2.75 \\
\hline $\begin{array}{l}\text { GCA X N/ } \\
\text { GCA X S }\end{array}$ & - & - & - & - & 1.00 & - & - & 1.09 \\
\hline $\begin{array}{l}\text { SCA X N/ } \\
\text { SCA X S }\end{array}$ & - & - & - & - & 0.65 & - & - & 0.99 \\
\hline
\end{tabular}

${ }^{*}$ and ${ }^{* *}$ significant at 0.05 and 0.01 probability levels, respectively. Abbreviations: $\mathrm{N}$, normal condition, $\mathrm{S}$, water stress condition

Table (2): Cont.

\begin{tabular}{|c|c|c|c|c|c|c|c|c|}
\hline \multirow{2}{*}{ S.O.V } & \multicolumn{2}{|c|}{ d.f } & \multicolumn{3}{|c|}{ Number of filled grains/panicle } & \multicolumn{3}{|c|}{ Sterility \% } \\
\hline & Single & Comb. & $\mathbf{N}$ & $\mathbf{S}$ & C & $\mathbf{N}$ & $\mathbf{S}$ & C \\
\hline $\mathbf{E}$ & - & 1 & - & - & $134,742.123^{\star *}$ & - & - & $4.941^{*}$ \\
\hline Replications & 2 & 5 & 0.27 & 0.18 & 26588.682** & 0.06 & 0.73 & $10.021^{\star *}$ \\
\hline Genotypes & 35 & 35 & $7589.47^{\star \star}$ & $5287.15^{\star \star}$ & $9196.871^{\star *}$ & $612.4^{\star *}$ & $252.53^{\star \star}$ & $538.964^{\star \star}$ \\
\hline Parents & 7 & 7 & $700.81^{\star \star}$ & $1551.93^{\star \star}$ & $1105.45^{\star \star}$ & $4.68^{\star \star}$ & $327.01^{\star \star}$ & $266.00^{\star \star}$ \\
\hline Crosses & 27 & 27 & $8747.49^{\star \star}$ & $5768.72^{\star \star}$ & $11630.17^{\star \star}$ & $792.5^{\star \star}$ & $206.97^{\star \star}$ & $595.50^{\star *}$ \\
\hline Parents vs. Crosses & 1 & 1 & $24543.67^{\star \star}$ & $18431.18^{\star \star}$ & $137.67^{\star \star}$ & 2.4 & $961.43^{\star \star}$ & $836.32^{\star \star}$ \\
\hline GXE & - & - & - & - & $1,623.669^{\star \star}$ & - & \begin{tabular}{|l|}
- \\
\end{tabular} & $99.014^{\star \star}$ \\
\hline PXE & - & - & - & - & $1147.29^{\star \star}$ & - & - & $65.69^{\star *}$ \\
\hline CrXE & - & - & - & - & $2,886.04^{\star \star}$ & - & - & $403.97^{\star \star}$ \\
\hline P vs. CXE & - & - & - & - & $42837.18^{\star \star}$ & - & - & $127.51^{\star \star}$ \\
\hline Error & 70 & 175 & 28.15 & 394.91 & 1281.578 & 2.93 & 32.56 & 58.179 \\
\hline GCA & 7 & 7 & $5133.16^{\star \star}$ & $1440.72^{\star \star}$ & - & $121.0^{\star \star}$ & $29.94^{\star \star}$ & - \\
\hline SCA & 28 & 28 & $1878.99^{\star \star}$ & $1842.80^{\star \star}$ & - & $224.9^{\star \star}$ & $97.74^{\star \star}$ & - \\
\hline GCA X E & - & - & - & - & $2734.902^{\star \star}$ & - & - & $48.640^{\star \star}$ \\
\hline SCA X E & - & - & - & - & $1232.289^{\star \star}$ & - & - & $100.124^{\star \star}$ \\
\hline Error term & 70 & 175 & 9.38 & 131.64 & 427.192 & 0.98 & 10.85 & 19.393 \\
\hline GCA/SCA & - & - & 0.274 & 0.08 & - & 0.054 & 0.022 & - \\
\hline GCA X E/ SCA X E & - & - & - & - & 2.21 & - & - & 0.48 \\
\hline GCA X N/ GCA X S & - & - & - & - & 3.56 & - & - & 4.04 \\
\hline SCA X N/ SCA X S & - & - & - & - & 1.01 & - & - & 2.30 \\
\hline
\end{tabular}

*and ${ }^{* *}$ significant at 0.05 and 0.01 probability levels, respectively. Abbreviations: $\mathrm{N}$ normal condition and $\mathrm{S}$ water stress condition 
R. A. El-Refaey, et al.,

Table (2): Cont.

\begin{tabular}{|c|c|c|c|c|c|}
\hline \multicolumn{2}{|c|}{ S.O.V } & d.f & \multicolumn{3}{c|}{ Grain yield/plant (g) } \\
\hline E & Single & Comb. & N & S & C \\
\hline Replications & - & 1 & - & - & $0.608^{\star *}$ \\
\hline Genotypes & 2 & 5 & 0.013 & 0.002 & 0.128 \\
\hline Parents & 35 & 35 & $0.510^{\star \star}$ & $0.267^{\star \star}$ & $0.572^{\star *}$ \\
\hline Crosses & 7 & 7 & 1.552 & 0.250 & 1.43 \\
\hline Parents vs. Crosses & 27 & 27 & 0.155 & 0.277 & 0.30 \\
\hline G X E & - & 1 & $2.800^{\star *}$ & 0.106 & 2.00 \\
\hline P X E & - & - & - & - & 0.090 \\
\hline Cr X E & - & - & - & - & $0.372^{\star *}$ \\
\hline P vs. C X E & - & - & - & - & 0.132 \\
\hline Error & 70 & 175 & 0.047 & 0.116 & 0.106 \\
\hline GCA & 7 & 7 & $0.404^{\star \star}$ & $0.321^{\star \star}$ & - \\
\hline SCA & 28 & 28 & $0.111^{\star *}$ & $0.311^{\star *}$ & - \\
\hline GCA X E & - & - & - & - & 0.336 \\
\hline SCA X E & - & - & - & - & 0.035 \\
\hline Error term & 70 & 175 & 0.016 & 0.039 & - \\
\hline GCA/SCA & - & - & 0.406 & -3.735 & - \\
\hline GCA X E/ SCA X E & - & - & - & - & 9.6 \\
\hline GCA X N/ GCA X S & - & - & -- & - & 1.25 \\
\hline SCA X N/ SCA X S & - & - & - & - & 3.58 \\
\hline
\end{tabular}

${ }^{*}$ and ${ }^{\star \star}$ significant at 0.05 and 0.01 probability levels, respectively. Abbreviations: $\mathrm{N}$ normal condition and $\mathrm{S}$ water stress condition

The interaction mean square of genotypes, parents, crosses and parent vs crosses with environments were found to be highly significant for all traits, except genotypes $x$ environment mean squares for grain yield / plant and crosses $x$ environments mean squares for grain yield /plant, which might indicated that genotypes, parents and crosses behaved in different way from normal condition to stress condition for most traits, while for parent vs crosses, $X$ environments mean squares which seems to be highly significant for all traits studied ,suggesting that heterotic variance might be differ from normal than at stress condition. These results are in agreement with those obtained by Singh and kumar (2005), Aidy et al., (2006), Hadifa (2012) and Abo - Omar (2015), where they found that the genotypes significantly differ from environment to another and parents and their crosses behaved in different way with changing the environments. The interaction of parent vs. crosses with environments was highly significant for all studied traits.

Analysis of variance for combining ability as outlined by Griffing (1965) method II model I in each environment for all the $s$ traits tidied and the combined analysis of the interactions between GCA and SCA variances with environments, where the significant, in this case, would be tested against error term mean squares are presented in Table (2).

Mean squares estimates for GCA and SCA were found to be highly significant for all traits studied under the two environments. These results indicated that, both additive and non-additive types of gene effects were involved and responsible for the expression of these traits. Mean squares estimates of GCA $x$ Env. and SCA $\times$ Env. were found to be highly significant for all traits studied, except for GCA $X$ Env. for grain yield /plant and SCA X Env. for plant height 
and grain yield /plant, where these interactions were not significant .This might indicate that, additive and non additive gene actions fluctuated from environment to another for most traits. While for the excepted traits it might be indicate that the additive and additive $x$ additive genes more stable from environment to another, and the excepted traits it might be indicated that non - additive gene actions not changed from environment to another.

The ratios of GCA/SCA mean squares were less than unity for all studied traits under normal as well as stress conditions, except for grain yield /plant under stress condition, where the ratio was more than one. This might indicate that, the non - additive gene actions were more responsible for the inheritance of these traits and bulk method would be the more suitable to done through the segregating generations. While, for grain yield /plant under stress condition, where the ratio was more than the unity, the additive and additive $x$ additive genes would be more important to expression the trait. In this case, the pedigree method would be more suitable to follow, and the selection would be more effective in the early segregating generations. However, the ratio was approximately equal one for No. of days to $50 \%$ heading at normal condition, suggesting that both additive and non. Additive would be involved in the inheritance of the trait

These findings are in the same line with those obtained by Abd - Elateef (2003), Abd - Allah (2004), Singh and kumar (2005), Hadifa (2012) and Abo Omar (2015).

The ratios of GCA x Env. /SCA x Env. mean squares were more than unity for No .of days to $50 \%$ heading, plant height, No of panicles /plant, No. of filled grains /panicle , 1000 - grain weight, grain yield /plant. This might indicate that, additive and additive $X$ additive gene effects were more interacted with environments than that non. additive genes effects. On the other hand, the ratios of GCA $x$ Env. I SCA $x$ Env. mean squares were less than unity for sterility \%, indicating that non additive gene action was more interacted with environments than additive do for this trait. On the others word, the first traits were more suitable to estimate additive and additive $x$ additive, while the second group of traits were more suitable to estimate non - additive gene action. The ratios of GCA $\times$ N /GCA $\times S$ mean squares were more than one for No. of days to $50 \%$ heading, plant height, No. of filled grains / plant, sterility \% and grain yield /plant. This might indicate that, additive and additive $x$ additive gene actions were more suitable to estimate under normal irrigation condition than with non - additive genes for these traits, Table (2).

However, the ratios of GCA x N/GCA x $S$ mean squares were equal one for No. of panicles /plant and 1000- grain weight, indicating that additive and additive $x$ additive gene effects could be suitable to estimate under normal as well as stress condition for these traits.

The ratios of SCA $\times \mathrm{N} /$ SCA $\times$ S mean squares were more than unity for plant height, No. of panicle /plant, 1000- grain weight, sterility \% and grain yield /plant, which might indicate that non - additive genes were more suitable to estimate under normal condition than that do under stress condition for these traits.

\section{Estimates of general and specific combining ability effects}

\subsection{General combining ability effects}

The estimates of general combining ability effects consider an important indicator of the potential of parental lines for generating superior breeding populations. A negligible or negative combining ability effects indicates a poor 
ability to transfer its genetic superiority to its hybrid. The largest significant positive values have the largest effects. On the other hand, the largest significant negative values have the smallest effects, except in case of sterility \% and earliness traits. Obviously, the results listed in Table (3) revealed that, the parental variety; IRAT170 behaved as an excellent combiner parent for plant height, No. of panicles / plant, 1000- grain weight, No. of filled grains/panicles and sterility \% due to its significant and /or highly significant $\left(g i^{\wedge}\right)$ in desirable directions under normal irrigation as well as stress condition, which might indicated that, the possibility to use this parent in hybrids to generate good lines of rice characteristics by high yielding potentiality via indirect selection of the traits in view under both environmental conditions. The parental varity; Morobroken had highly significant ( $\left.g \mathrm{i}^{\wedge}\right)$ in desirable direction for plant height No. of panicles /plant, 1000- grain weight and No. of filled grains / panicle under normal irrigation condition and for No. of days to $50 \%$ heading and plant height at stress condition. The parental verities; Giza 177, Giza 178 and Giza 179 behaved as good combiner parents for No. of days to $50 \%$ heading under both environmental conditions due to their highly significant $\left(g^{i}\right)$ in negative direction, indicating that these parental varieties could possessed earliness to the hybrids which revolved and the parental variety; Sakha 104 considered as good combiner parent for plant height, No. of panicles /plant and sterility \%, where its $\left(\mathbf{g i}^{\wedge}\right)$ were significant for the traits in view under normal irrigation condition.

However, some parents with high mean values exhibited low GCA effects. Hence, both performances per se and $\left(g^{\wedge}{ }^{\wedge}\right)$ should be taken into account for parental selection. Similar results were obtained previously by El Abd et al., (2007), Viswanathan and Thiyagarajan (2008) Muthuramu et al., (2010) and ElNaem (2010).

Table 3: Estimates of general combining ability effects for yield and its compounder traits for parental genotypes under normal and water stress conditions.

\begin{tabular}{|c|c|c|c|c|c|c|c|}
\hline \multirow{2}{*}{ No. } & \multirow{2}{*}{ Parent } & \multicolumn{2}{|c|}{$\begin{array}{l}\text { Number of days to } \\
50 \% \text { heading (day) }\end{array}$} & \multicolumn{2}{|c|}{ Plant height (cm) } & \multicolumn{2}{|c|}{$\begin{array}{c}\text { Number of } \\
\text { panicles/plant }\end{array}$} \\
\hline & & $\mathbf{N}$ & $\mathbf{S}$ & $\mathbf{N}$ & $\mathbf{S}$ & $\mathbf{N}$ & $\mathbf{S}$ \\
\hline 1 & Sakha 104 & $11.33^{\star *}$ & $11.15^{\star *}$ & $-0.56^{\star}$ & 1.39 & $3.10^{\star}$ & $-3.98^{\star *}$ \\
\hline 2 & Sakha 106 & $-3.43^{\star \star}$ & -0.35 & 0.16 & $1.97^{\star \star}$ & $-3.40^{\star}$ & $2.52^{\star \star}$ \\
\hline 3 & Giza 177 & $-2.57^{\star *}$ & $-3.38^{\star *}$ & -0.02 & -1.18 & $-6.60^{\star *}$ & $-8.38^{\star *}$ \\
\hline 4 & Giza 178 & $-2.40^{\star *}$ & $-2.75^{\star \star}$ & $1.78^{\star \star}$ & $2.35^{\star \star}$ & $-11.63^{\star *}$ & 0.62 \\
\hline 5 & Giza 179 & $-4.90^{\star \star}$ & $-1.78^{\star}$ & 0.41 & $1.90^{\star \star}$ & $-10.03^{\star *}$ & -1.28 \\
\hline 6 & IET1444 & -0.23 & 0.82 & $4.64^{\star \star}$ & $1.65^{\star}$ & $3.87^{\star *}$ & $7.49^{* *}$ \\
\hline 7 & IRAT170 & $-2.00^{\star *}$ & -1.32 & $-5.11^{\star *}$ & $-4.60^{\star *}$ & $9.80^{\star \star}$ & $8.56^{* *}$ \\
\hline 8 & Morobroken & $4.20^{\star \star}$ & $-2.38^{\star \star}$ & $-1.29^{\star *}$ & $-3.50^{\star \star}$ & $14.90^{\star *}$ & $-5.58^{\star *}$ \\
\hline \multicolumn{2}{|c|}{ L.S.D 0.05} & 0.53 & 1.63 & 2.71 & 0.54 & 1.39 & 1.80 \\
\hline & 0.01 & 0.70 & 2.16 & 3.60 & 0.72 & 1.86 & 2.40 \\
\hline
\end{tabular}

*and ${ }^{\star *}$ significant at 0.05 and 0.01 probability levels, respectively. Abbreviations: $\mathbf{N}$ normal condition and $\mathrm{S}$ water stress condition 
Studies on combining ability for grain yield and its components traits in

Table 3: Cont.

\begin{tabular}{|c|c|c|c|c|c|c|c|c|c|}
\hline \multirow[t]{2}{*}{ No. } & \multirow[t]{2}{*}{ Parents } & \multicolumn{2}{|c|}{$\begin{array}{l}\text { 1000-grain weight } \\
\text { (g) }\end{array}$} & \multicolumn{2}{|c|}{$\begin{array}{l}\text { Number of filled } \\
\text { grains/panicle }\end{array}$} & \multicolumn{2}{|c|}{ Sterility \% } & \multicolumn{2}{|c|}{$\begin{array}{c}\text { Grain yield/plant } \\
(\mathrm{g})\end{array}$} \\
\hline & & $\mathbf{N}$ & $\mathrm{S}$ & $\mathbf{N}$ & $\mathbf{S}$ & $\mathbf{N}$ & $\mathbf{S}$ & $\mathbf{N}$ & $S$ \\
\hline 1 & Sakha 104 & $-0.45^{\star \star}$ & -0.16 & 1.0 & $8.88^{*}$ & $-3.49^{\star *}$ & -0.26 & -0.84 & 0.26 \\
\hline 2 & Sakha 106 & $-0.38^{* *}$ & 0.31 & $12.7^{\star \star}$ & $-7.16^{\star}$ & $0.70^{\star}$ & $2.13^{*}$ & $7.82^{\star *}$ & 4.51 \\
\hline 3 & Giza 177 & -0.07 & 0.12 & $-29.8^{* \star}$ & $-20.76^{\star \star}$ & $-1.69^{* *}$ & 0.66 & $-6.59^{* *}$ & $-6.36^{*}$ \\
\hline 4 & Giza 178 & $-2.59^{\star \star}$ & $-1.00^{\star \star}$ & $-10.7^{\star \star}$ & -2.17 & $-2.58^{\star \star}$ & -0.91 & $-2.64^{\star}$ & -3.88 \\
\hline 5 & Giza 179 & $0.94^{\star *}$ & $-1.50^{* \star}$ & $-32.5^{\star \star}$ & $-7.55^{\star}$ & $2.03^{\star *}$ & 1.18 & -1.03 & -2.36 \\
\hline 6 & IET1444 & 0.05 & -0.35 & $14.8^{\star \star}$ & 5.43 & $5.35^{\star \star}$ & $-2.40^{\star}$ & $16.56^{\star \star}$ & $9.18^{\star \star}$ \\
\hline 7 & IRAT170 & $1.65^{\star \star}$ & $2.62^{\star \star}$ & $13.3^{\star \star}$ & $18.15^{\star \star}$ & $-4.02^{\star \star}$ & $-2.18^{\star}$ & $-14.41^{\star *}$ & 0.95 \\
\hline 8 & Morobroken & $0.84^{\star \star}$ & -0.05 & $31.3^{\star \star}$ & 5.18 & $3.70^{\star \star}$ & 1.77 & 1.12 & -2.30 \\
\hline \multicolumn{2}{|c|}{ L.S.D 0.05} & 0.26 & 0.51 & 1.81 & 6.79 & 0.58 & 1.95 & 2.60 & 6.02 \\
\hline & 0.01 & 0.34 & 0.68 & 2.41 & 9.03 & 0.78 & 2.59 & 3.46 & 8.01 \\
\hline
\end{tabular}

*and ${ }^{\star \star}$ significant at 0.05 and 0.01 probability levels, respectively. Abbreviations: $\mathrm{N}$ normal condition and $S$ water stress condition

\subsection{Specific combining ability (SCA) effects for grain yield and its components traits.}

High specific combining ability effects were caused by the dominance and nonallelic interactions or epistatic effects (non-fixable genes) that existed between the crossed parents. The same can be used as an index to determine the usefulness of a particular crosscombination in the exploitation of heterosis. As shown in Table 4, the cross; Sakha 106 x Giza 179 had significant $\left(\bar{S}_{\text {ij }}\right)$ in favorable direction under normal condition for No. of days to $50 \%$ heading ,No. of filled grains /plant ,sterility\% and grain yield/ plant, the cross ; Giza 177 x IET 444 for No .of days to $50 \%$ heading, and sterility \%, the cross ; Sakha 104 x Morobroken for No. of panicles /plant , No. of filled grains/ panicle and grain yield /plant under normal condition; the cross ; Giza $177 \times$ Morobroken for No - of days to $50 \%$ heading, No .of panicles / plant, No. of filled grains / panicle ,1000 - grain weight and grain yield /plant under normal condition , the cross ;Giza 178 x Giza 179 for No . of days to $50 \%$ heading , plant height No .of filled grains /panicle , sterility \%, under normal condition The cross ;Giza $178 \times$ Morobroken for plant height ,No. of panicles / plant, sterility \% ,grain yield /plant under normal condition, the cross ; IETI $444 \mathrm{x}$ Morobroken for No . of days to $50 \%$ heading, 1000 - grain weight, No .of filled grains /panicle and sterility \% under normal condition. These crosses could be used either at normal or at stress conditions as good genetic materials as promising hybrids from the commercial point of view or with follow bulk method in the segregating generations to generate some good pure lines of rice characterized by high yielding and earlier maturity.

The superiority of these crosses may be due to complementary and duplicate type of gene interactions. Hence, these hybrids are expected to produce desirable segregates and could be exploited successfully in breeding programs. Similar trend\% findings were reported earlier by Dhakar and vinit (2006), El-Naem (2010) and Negm (2011). 
R. A. El-Refaey, et al.,

Table 4: Estimates of specific combining ability effects for yield and its components traits in $\mathbf{F} 1$ crosses under normal and water stress conditions.

\begin{tabular}{|c|c|c|c|c|c|}
\hline \multirow[t]{2}{*}{ No. } & \multirow[t]{2}{*}{ Crosses } & \multicolumn{2}{|c|}{$\begin{array}{c}\text { Number of days to } 50 \% \\
\text { heading (day) }\end{array}$} & \multicolumn{2}{|c|}{ Plant height $(\mathbf{c m})$} \\
\hline & & $\mathbf{N}$ & $S$ & $\mathbf{N}$ & $S$ \\
\hline 1 & Sakha 104 x Sakha 106 & $2.32^{\star \star}$ & $-7.04^{\star \star}$ & $-9.26^{*}$ & $-15.08^{\star *}$ \\
\hline 2 & Sakha 104 x Giza 177 & $3.79^{* *}$ & 0.99 & -4.39 & -1.18 \\
\hline 3 & Sakha 104 x Giza 178 & $6.62^{\star *}$ & $11.36^{\star \star}$ & $21.31^{\star *}$ & $16.82^{\star \star}$ \\
\hline 4 & Sakha 104 x Giza 179 & $8.79 * *$ & $13.06^{* *}$ & $15.38^{\star \star}$ & $9.72^{\star \star}$ \\
\hline 5 & Sakha 104 x IET1444 & $6.12^{\star \star}$ & $10.79^{\star \star}$ & $13.48^{* *}$ & $16.96^{\star \star}$ \\
\hline 6 & Sakha 104 x IRAT170 & $4.22^{* \star}$ & $7.26^{\star \star}$ & 3.88 & $11.89^{\star \star}$ \\
\hline 7 & Sakha 104 x Morbroken & $3.69^{* *}$ & -2.67 & $9.11^{*}$ & $-14.64^{\star *}$ \\
\hline 8 & Sakha 106 x Giza 177 & $-2.78^{\star \star}$ & $14.49^{\star \star}$ & $-19.56^{\star *}$ & $24.99^{\star \star}$ \\
\hline 9 & Sakha 106 x Giza 178 & -0.94 & -2.47 & $19.14^{\star *}$ & 4.32 \\
\hline 10 & Sakha 106 x Giza 179 & $-2.44^{\star *}$ & $-7.11^{\star \star}$ & 5.88 & $-5.78^{\star}$ \\
\hline 11 & Sakha 106 x IET1444 & $3.89^{\star \star}$ & 0.29 & $26.31^{\star *}$ & $10.79^{\star *}$ \\
\hline 12 & Sakha 106 x IRAT170 & -1.34 & $-4.91^{*}$ & 4.38 & 3.06 \\
\hline 13 & Sakha 106 x Morbroken & $-1.88^{\star *}$ & -4.17 & $8.94^{*}$ & $-18.14^{\star *}$ \\
\hline 14 & Giza 177 x Giza 178 & $2.19^{\star *}$ & 3.89 & $19.68^{* *}$ & $10.89^{* *}$ \\
\hline 15 & Giza 177 x Giza 179 & 1.02 & -2.41 & 7.08 & -0.21 \\
\hline 16 & Giza 177 x IET1444 & $-3.31^{\star *}$ & -0.67 & $17.51^{\star \star}$ & $19.36^{\star *}$ \\
\hline 17 & Giza 177 x IRAT170 & -0.88 & -1.54 & 3.91 & 2.62 \\
\hline 18 & Giza 177 x Morobroken & $-7.74^{\star *}$ & -1.81 & $15.48^{* \star}$ & $-7.91^{\star \star}$ \\
\hline 19 & Giza 178 x Giza 179 & $-3.14^{\star *}$ & -4.04 & $-15.89^{* *}$ & $-18.21^{* \star}$ \\
\hline 20 & Giza 178 x IET1444 & $-4.14^{\star \star}$ & -0.31 & -5.12 & $-23.31^{* *}$ \\
\hline 21 & Giza 178 x IRAT170 & $-2.71^{\star *}$ & -1.84 & $7.94^{*}$ & -3.04 \\
\hline 22 & Giza 178 x Morobroken & 0.09 & -3.77 & $-38.49^{\star \star}$ & $-21.24^{\star \star}$ \\
\hline 23 & Giza 179 x IET1444 & -0.64 & $-5.27^{\star}$ & $-25.39^{\star \star}$ & $-22.74^{* *}$ \\
\hline 24 & Giza 179 x IRAT170 & 1.12 & 1.53 & 2.01 & -1.81 \\
\hline 25 & Giza 179 x Morobroken & -0.08 & -0.41 & $23.24^{\star \star}$ & -0.34 \\
\hline 26 & IET1444x IRAT170 & $2.46^{* *}$ & 1.59 & $19.78^{\star \star}$ & $-6.58^{\star \star}$ \\
\hline 27 & IET1444x Morobroken & $-4.41^{\star \star}$ & -0.67 & $11.34^{\star \star}$ & -3.44 \\
\hline 28 & IRAT170x Morobroken & -0.64 & -3.54 & 5.74 & 2.49 \\
\hline \multirow[t]{2}{*}{ L.S.D } & 0.05 & 1.40 & 4.34 & 7.22 & 4.81 \\
\hline & 0.01 & 1.86 & 5.77 & 9.61 & 6.40 \\
\hline
\end{tabular}

*and ${ }^{* \star}$ significant at 0.05 and 0.01 probability levels, respectively. Abbreviations: $\mathrm{N}$ normal condition and $\mathrm{S}$ water stress condition. 
Studies on combining ability for grain yield and its components traits in

Table 4: Cont.

\begin{tabular}{|c|c|c|c|c|c|}
\hline \multirow[t]{2}{*}{ No. } & \multirow[t]{2}{*}{ Crosses } & \multicolumn{2}{|c|}{$\begin{array}{c}\text { Number of panicles } \\
\text { /plant }\end{array}$} & \multicolumn{2}{|c|}{$\begin{array}{c}\text { 1000-grain weight } \\
(\mathrm{g})\end{array}$} \\
\hline & & $\mathbf{N}$ & $\mathbf{S}$ & $\mathbf{N}$ & $\mathbf{S}$ \\
\hline 1 & Sakha 104 x Sakha 106 & $1.48^{\star}$ & $-7.19^{\star *}$ & $1.88^{\star \star}$ & $1.42^{*}$ \\
\hline 2 & Sakha 104 x Giza 177 & $-6.17^{\star \star}$ & $-8.04^{\star \star}$ & $-4.96^{\star \star}$ & 0.28 \\
\hline 3 & Sakha 104 x Giza 178 & $-3.30^{\star *}$ & $14.10^{\star \star}$ & $2.77^{\star \star}$ & -0.43 \\
\hline 4 & Sakha 104 x Giza 179 & -0.93 & $9.88^{\star \star}$ & 0.13 & $3.27^{\star *}$ \\
\hline 5 & Sakha 104 x IET1444 & $-8.83^{* *}$ & $10.80^{\star *}$ & $-1.07^{\star \star}$ & 0.92 \\
\hline 6 & Sakha 104 x IRAT170 & $1.92^{*}$ & $-5.62^{\star \star}$ & $2.03^{\star \star}$ & $-1.65^{\star}$ \\
\hline 7 & Sakha 104 x Morbroken & $2.77^{\star *}$ & 0.61 & 0.33 & -1.26 \\
\hline 8 & Sakha 106 x Giza 177 & $-3.55^{\star *}$ & -1.62 & $-5.94^{\star *}$ & -0.03 \\
\hline 9 & Sakha 106 x Giza 178 & 0.98 & $8.51^{\star \star}$ & $1.72^{\star \star}$ & -0.31 \\
\hline 10 & Sakha 106 x Giza 179 & -0.82 & $4.30^{*}$ & $1.79^{\star \star}$ & 0.56 \\
\hline 11 & Sakha 106 x IET1444 & $14.12^{\star *}$ & $8.21^{\star \star}$ & 0.62 & $-2.39^{\star \star}$ \\
\hline 12 & Sakha 106 x IRAT170 & $3.53^{\star *}$ & 3.63 & $2.78^{\star \star}$ & $1.87^{\star \star}$ \\
\hline 13 & Sakha 106 x Morbroken & 0.05 & -1.30 & $0.89^{\star}$ & 0.47 \\
\hline 14 & Giza 177 x Giza 178 & $11.50^{\star *}$ & $9.33^{\star \star}$ & $1.95^{\star \star}$ & $-1.79^{\star}$ \\
\hline 15 & Giza 177 x Giza 179 & $8.53^{\star \star}$ & $8.11^{\star \star}$ & $-2.95^{\star \star}$ & $-5.25^{\star \star}$ \\
\hline 16 & Giza 177 x IET1444 & 0.80 & -1.97 & $1.91^{* *}$ & -0.47 \\
\hline 17 & Giza 177 x IRAT170 & $-2.28^{* *}$ & -1.39 & 0.24 & $3.93^{\star \star}$ \\
\hline 18 & Giza 177 x Morobroken & $2.90^{* *}$ & 0.85 & $2.68^{* *}$ & 1.14 \\
\hline 19 & Giza 178 x Giza 179 & $-7.43 * 8$ & $-5.75^{\star \star}$ & 0.64 & $-2.10^{\star *}$ \\
\hline 20 & Giza 178 x IET1444 & $-5.50^{\star \star}$ & -3.34 & $-1.438^{\star *}$ & $-5.11^{\star *}$ \\
\hline 21 & Giza 178 x IRAT170 & $6.75^{\star *}$ & $8.08^{\star *}$ & $3.07^{\star *}$ & 0.75 \\
\hline 22 & Giza 178 x Morobroken & $1.93^{\star}$ & -1.19 & $-6.06^{\star \star}$ & $-2.54^{\star \star}$ \\
\hline 23 & Giza 179 x IET1444 & -1.13 & -2.05 & -0.47 & $-2.71^{\star *}$ \\
\hline 24 & Giza 179 x IRAT170 & -0.55 & -0.47 & $1.97^{\star \star}$ & 1.02 \\
\hline 25 & Giza 179 x Morobroken & $-6.53^{* *}$ & 2.60 & $4.57^{* *}$ & $2.76^{\star *}$ \\
\hline 26 & IET1444x IRAT170 & $3.05^{\star \star}$ & $-8.89^{\star \star}$ & -0.21 & $5.63^{\star \star}$ \\
\hline 27 & IET1444x Morobroken & -0.77 & $-3.82^{*}$ & $2.40^{\star *}$ & 0.31 \\
\hline 28 & IRAT170x Morobroken & $-5.35^{\star \star}$ & $-4.74^{\star}$ & -0.54 & $-2.27^{\star \star}$ \\
\hline \multirow[t]{2}{*}{ L.S.D } & 0.05 & 1.45 & 3.72 & 0.68 & 1.36 \\
\hline & 0.01 & 1.93 & 4.95 & 0.91 & 1.80 \\
\hline
\end{tabular}

${ }^{\star}$ and ${ }^{\star \star}$ significant at 0.05 and 0.01 probability levels, respectively. Abbreviations: $\mathrm{N}$ normal condition and $\mathrm{S}$ water stress condition. 
R. A. El-Refaey, et al.,

Table 4: Cont.

\begin{tabular}{|c|c|c|c|c|c|c|c|}
\hline \multirow[t]{2}{*}{ No. } & \multirow[t]{2}{*}{ Crosses } & \multicolumn{2}{|c|}{$\begin{array}{c}\text { Number of filled } \\
\text { grains } \\
\text { /panicle }\end{array}$} & \multicolumn{2}{|c|}{$\begin{array}{c}\text { Sterility } \\
\%\end{array}$} & \multicolumn{2}{|c|}{$\begin{array}{c}\text { Grain yield/plant } \\
\text { (g) }\end{array}$} \\
\hline & & $\mathbf{N}$ & $S$ & $\mathbf{N}$ & $S$ & $\mathbf{N}$ & $S$ \\
\hline 1 & Sakha 104 x Sakha 106 & $-8.06^{\star \star}$ & 9.59 & $5.90^{* *}$ & -1.62 & 4.52 & -12.99 \\
\hline 2 & Sakha 104 x Giza 177 & $-10.88^{\star *}$ & 1.19 & $-2.81^{\star *}$ & $11.04^{\star \star}$ & $-16.07^{\star \star}$ & -9.78 \\
\hline 3 & Sakha 104 x Giza 178 & $41.40^{\star \star}$ & $-36.07^{\star \star}$ & $-2.04^{*}$ & $-8.08^{\star \star}$ & $13.32^{\star \star}$ & $19.74^{\star}$ \\
\hline 4 & Sakha 104 x Giza 179 & $-25.16^{\star \star}$ & $-53.02^{\star \star}$ & $-7.44^{\star \star}$ & $-10.72^{\star \star}$ & $-7.13^{\star}$ & -2.62 \\
\hline 5 & Sakha 104 x IET1444 & $6.90^{\star \star}$ & $-20.67^{\star}$ & $-9.21^{\star \star}$ & $-5.40^{\star}$ & -4.38 & $17.50^{*}$ \\
\hline 6 & Sakha 104 x IRAT170 & $8.40^{* *}$ & $117.61^{\star \star}$ & 1.34 & 4.03 & 6.65 & $32.40^{\star \star}$ \\
\hline 7 & Sakha 104 x Morbroken & $20.08^{\star \star}$ & -0.65 & $2.46^{\star *}$ & $7.93^{\star \star}$ & $12.39^{\star \star}$ & -0.04 \\
\hline 8 & Sakha 106 x Giza 177 & $8.93^{\star \star}$ & $44.75^{\star \star}$ & $2.74^{\star \star}$ & $18.81^{\star \star}$ & -6.13 & $22.50^{\star \star}$ \\
\hline 9 & Sakha 106 x Giza 178 & $-18.96^{\star \star}$ & -18.03 & $-6.40^{\star \star}$ & $-9.49^{\star \star}$ & 3.99 & -6.35 \\
\hline 10 & Sakha 106 x Giza 179 & $-46.52^{\star \star}$ & $-52.98^{\star \star}$ & $-11.67^{\star \star}$ & $-13.12^{\star \star}$ & $-18.46^{\star \star}$ & -3.87 \\
\hline 11 & Sakha 106 x IET1444 & $24.20^{\star *}$ & 16.37 & $-9.99^{* *}$ & $-6.62^{*}$ & $72.79^{\star \star}$ & $29.92^{\star \star}$ \\
\hline 12 & Sakha 106 x IRAT170 & $47.04^{\star \star}$ & $43.32^{* \star}$ & $-2.98^{\star \star}$ & -1.60 & $-7.41^{*}$ & -1.85 \\
\hline 13 & Sakha 106 x Morbroken & $71.38^{\star \star}$ & 0.88 & $29.15^{\star \star}$ & $10.62^{\star \star}$ & -6.44 & $-16.23^{*}$ \\
\hline 14 & Giza 177 x Giza 178 & $-35.78^{\star \star}$ & $-31.43^{\star \star}$ & $-4.70^{\star \star}$ & $-9.34^{\star \star}$ & 0.39 & -4.81 \\
\hline 15 & Giza 177 x Giza 179 & $-42.34^{\star \star}$ & $-49.38^{\star \star}$ & $-9.46^{\star \star}$ & $-11.74^{\star \star}$ & $23.45^{\star \star}$ & 4.00 \\
\hline 16 & Giza 177 x IET1444 & $-25.95^{\star \star}$ & $23.63^{\star}$ & $-10.99^{\star \star}$ & -4.68 & $-10.47^{\star \star}$ & 0.46 \\
\hline 17 & Giza 177 x IRAT170 & $48.88^{* *}$ & 7.59 & $6.73^{\star \star}$ & $-5.21^{*}$ & 3.16 & 0.02 \\
\hline 18 & Giza 177 x Morobroken & $46.90^{\star \star}$ & $29.78^{\star \star}$ & $21.75^{\star \star}$ & 0.61 & $10.97^{\star \star}$ & -2.49 \\
\hline 19 & Giza 178 x Giza 179 & $51.60^{\star \star}$ & $23.36^{\star}$ & $-6.81^{\star \star}$ & $14.97^{\star \star}$ & $-12.66^{\star \star}$ & -13.15 \\
\hline 20 & Giza 178 x IET1444 & $32.66^{\star \star}$ & -2.63 & $15.68^{\star \star}$ & -0.51 & $-18.42^{\star \star}$ & -5.69 \\
\hline 21 & Giza 178 x IRAT170 & $-44.18^{\star \star}$ & $-43.67^{\star \star}$ & $-1.81^{\star \star}$ & -5.05 & 1.22 & 10.54 \\
\hline 22 & Giza 178 x Morobroken & $-35.83^{\star *}$ & -3.74 & $-7.66^{\star \star}$ & $5.98^{\star}$ & $10.02^{\star \star}$ & 7.03 \\
\hline 23 & Giza 179 x IET1444 & $-18.57^{\star \star}$ & -9.91 & $55.71^{\star \star}$ & $9.94^{\star *}$ & 2.47 & -2.88 \\
\hline 24 & Giza 179 x IRAT170 & -0.40 & $-25.62^{\star \star}$ & $-6.31^{\star \star}$ & $-8.07^{\star \star}$ & $10.94^{\star \star}$ & 10.35 \\
\hline 25 & Giza 179 x Morobroken & $43.28^{\star \star}$ & 17.12 & $-7.85^{\star \star}$ & -2.78 & $-13.26^{\star \star}$ & 11.64 \\
\hline 26 & IET1444x IRAT170 & $56.99^{\star \star}$ & $-52.61^{* *}$ & $-6.13^{\star \star}$ & $11.72^{\star \star}$ & $-28.98^{\star *}$ & $-20.19^{*}$ \\
\hline 27 & IET1444x Morobroken & $26.34^{\star \star}$ & 3.43 & $-15.91^{\star *}$ & $-7.97^{\star \star}$ & 1.82 & $-16.80^{*}$ \\
\hline 28 & IRAT170x Morobroken & $14.17^{\star \star}$ & $-27.55^{\star *}$ & $-6.03^{\star \star}$ & 3.37 & -6.21 & $-16.87^{*}$ \\
\hline \multirow[t]{2}{*}{ L.S.D } & D 0.05 & 4.83 & 18.10 & 1.56 & 5.20 & 6.93 & 16.06 \\
\hline & 0.01 & 6.43 & 24.07 & 2.07 & 6.91 & 9.22 & 21.36 \\
\hline
\end{tabular}

*and ${ }^{* *}$ significant at 0.05 and 0.01 probability levels, respectively. Abbreviations: $\mathbf{N}$ normal condition and $S$ water stress condition.

\section{REFERENCES}

Abd Allah, A.A. (2004). A breeding study on drought tolerance in rice (Oryza sativa L.). Egyptian J. of Agric. Res. 82(1): 149-165.
Abo-Omar, M.A.M. (2015). Breeding studies on rice (Oryza sativa L.). M.Sc. Thesis, Fac. of Agric., Kafr El-Sheikh Univ., Egypt.

Abd El-Lattef, A.S. (2003). Studies on behavior of some characters related to 
drought tolerance in rice breeding. Ph.D. Thesis, Fac. of Agric. Kafr ElSheikh, Tanta Univ., Egypt.

Butany, W. T. (1961). Mass emasculation in rice. Inster. Rice Comm. Newsletter. 9: 9-13.

Chang, T. T. and G. C. Loresto. 1986. Screening techniques for drought resistance in rice. In Approaches for Incorporating Drought and Salinity Resistance in Crop Plants, edited by V. L. Chopra and R. S. Paroda. 108-29.

Dhakar, J. M. and V. Vinit (2006). Combining ability analysis in rice (Oryza sativa). Crop Research Hisar, 31(3): 378-379.

Dudley, J. W. and R. H. Moll (1969). Interpretation and use of estimates of heritability and genetic variance in plant breeding. Crop Sci. 9: 257-262.

El-Hity, M.A., M.S. Abd El-Aty, A.M.Y. Hadifa and M. Abo-Omar (2015). Combining ability for yield and some agronomic characters as indices of drought tolerance in rice (Oryza sativa L.). J. Agric. Res. Kafr El-Sheikh Univ., 41(4).

EL-Abd, A. B., A. A. Abd Allah, S. M. Shehata, A. S. M. Abd El-Lateef and B. A. Zayed (2007). Heterosis and combining ability for yield and its components and some root characters in rice under water stress conditions. Proc. Fifth Plant Breeding Conference, May 27. Egypt. J. Plant Breeding, Special Issue, 11 (2): 593609.

El-Naem, S, M, A. (2010). Breeding studies on rice (Oryza sativa L.) under water stress conditions. M.Sc. Agron. Fac. of Agric, Mansoura Univ., Egypt.

Griffing, B. (1956 a). A generalized treatment of the use of diallel crosses in quantitative inheritance. Heredity, 10: 31-50.

Griffing, B. (1956 b). Concept of general and specific combining ability in relation to diallel crossing systems. Aust. J. Biol. Sci., 9: 463-493.

Gaballah, M.M. (2009). Studies on physiological and morphological traits associated with drought resistance in rice (Oryza sativa, L.). Ph.D. Thesis, Agron., Dept., Fac. Agric., KafrelSheikh Univ., Egypt, pp. 212.

Hadifa, A.A.Y. (2012). The role of root and shoot characteristics in rice drought tolerance. Ph. D. Thesis, Fac. Agric. Kafr El-Sheikh Univ. Egypt.

IRRI (International Rice Research Institute). (1996). Standard Evaluation System for Rice. International Rice Research Institute (IRRI), P.O. Box 933, 1099 Manila, Philippines.

Jodon, N. E. 1938. Experiment on artificial hybridization of rice. J. Amer. Soci. Argon., 30: 249-305.

Muthuramu, S., S. Jebaraj, R. Ushakumari and M. Gnanasekaran (2010). Estimation of combining ability and heterosis for drought tolerance in different locations in rice (Oryza sativa L.). Electronic Journal of Plant Breeding. 1 (5): 1279-1285.

Negm, M.E.A.A. (2011). Genetical studies on some physiological characters of salinity tolerance in rice. M.Sc. Thesis, Fac. of Agric., Kafr EISheikh University, Egypt.

Pickett, A. A. (1993). Hybrid Wheat-Result and Problems. Plant breeding 15. Berlin : Paul Parey Sc Publish, pp. 158.

Snedecor, G.W. and W. G. Cochran (1967). Statistical Methods $6^{\text {th }}$ ed. lowa State University Press, Amer, lowa, USA.

Singh, R. K. and B. D. Chaudhary. 1979. Biometrical Methods in Quantitative Genetic Analysis. Kalyani Publ., New Delhi.

Singh, N.K. and A. Kumar (2005). Combining ability analysis to identify suitable parents for heterotic rice hybrid breeding. IRRN. 29(1): 21-22. 
تقدير القدره علي الائتلاف لمحصول الحبوب ومكوناته فى الارز تحت ظروف الري العادي والاجهاد المائى

رمضان علي الرفاعي(')، عبد المعطي بسيوني العبد(؟)، محمد عبد الرحمن فتياني(؟)

(1) قسم المحاصيل - كليه الزراعه - جامعه طنطا - جمهوريه مصر العربيه

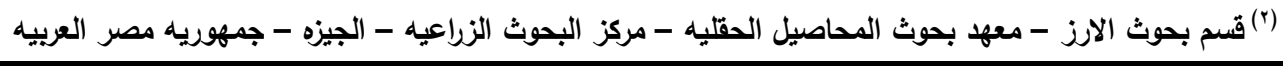

الملخص العربي

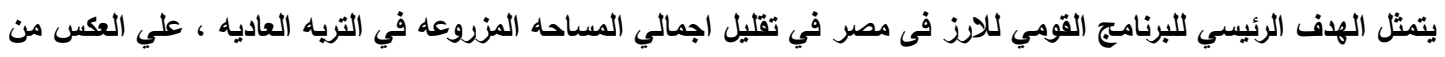

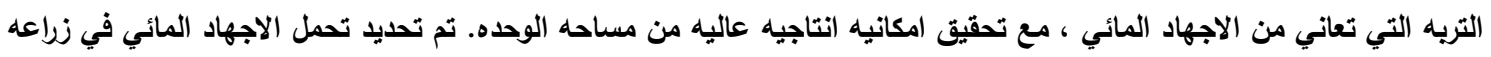

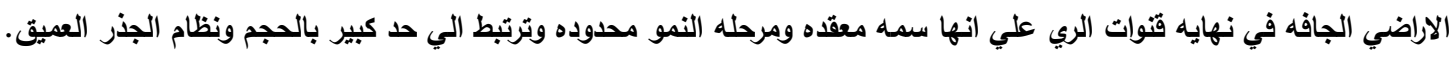

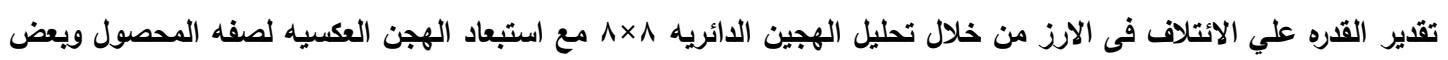

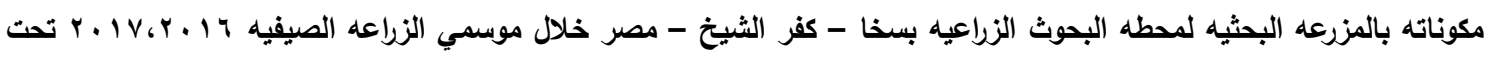
ظروف الري العادي والاجهاد المائي .

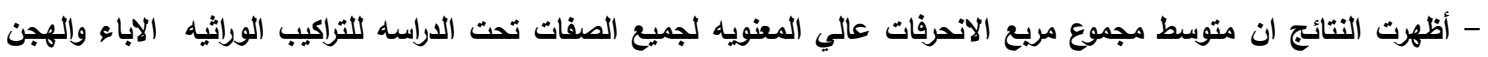

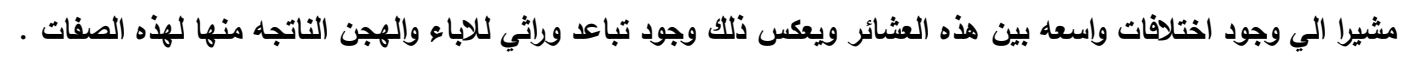

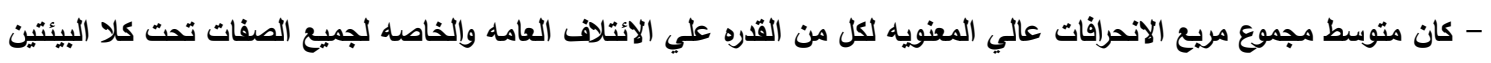

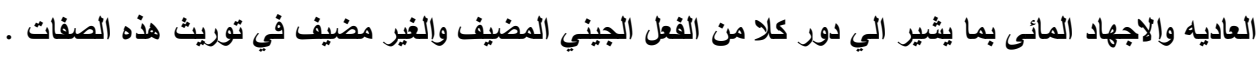

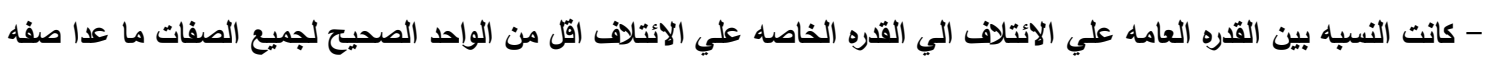

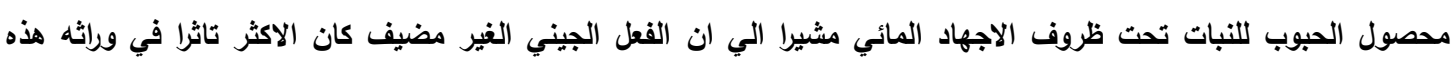

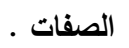
- اظهرت الاصناف الابويه Morobroken , IRAT170 كاصناف جيده التألف لصفه محصول الحبوب للنبات وبعض الصفات

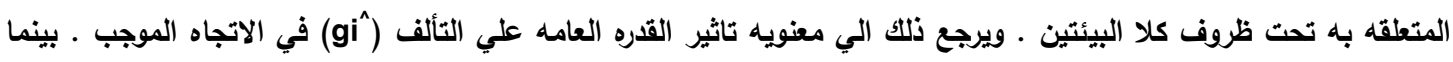

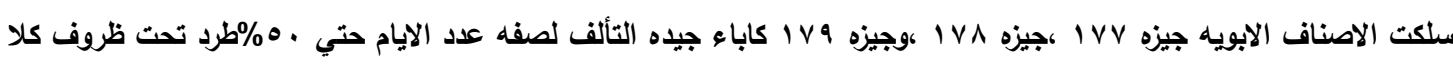

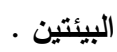

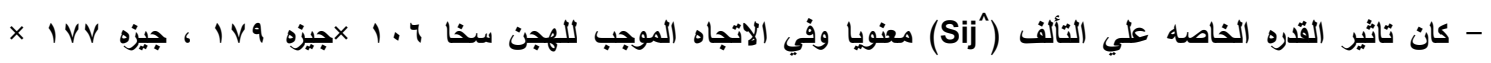

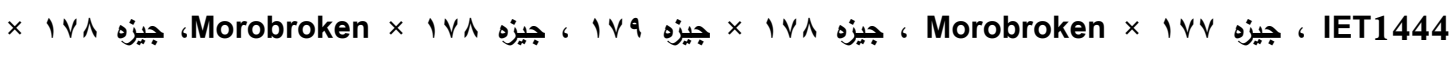

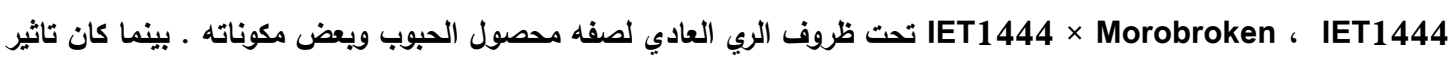

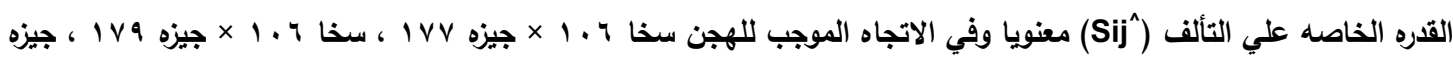

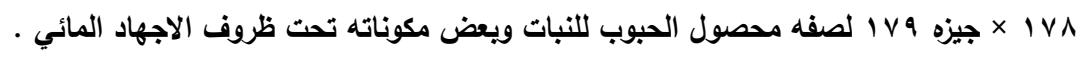


Studies on combining ability for grain yield and its components traits in ...........

أ.د/ حسان عبدالجيد دوام كلية الزراعة - جامعة المنوفية 